\title{
EFFECT OF VITAMIN E-SELENIUM SUPPLEMENTATION ON SOME SEMEN QUALITY TRAITS OF MUSCOVY DRAKES
}

\author{
Safaa $^{1^{\star}}$ A.M. Ali, El-Wardany ${ }^{2}$ I., Hassan ${ }^{2}$ A.M. and Amal M. Hassan ${ }^{1}$ \\ 1- Animal and Poultry Production Division, Animal and Poultry Physiology Dept., \\ Desert Research Center, Cairo, Egypt \\ 2- Poultry Production Dept., Fac. of Agric., Ain Shams Univ., P.O. Box 68, Hadayek Shoubra \\ 11241, Cairo, Egypt.
}

*Corresponding author: safaaali30@yahoo.com

Received 30 April, 2019

\author{
Accepted 30 May, 2019
}

\section{ABSTRACT}

A total of 12 , (36-week-old) of Muscovy drakes were divided randomly into three equal groups (4 individuals each) and subjected to supplementation of VE-Se in combine form in drinking water. The first group was served as control group (C), while the second and third groups $\left(T_{1}\right.$ and $\left.T_{2}\right)$ were supplemented with $1.0 \mathrm{~g} / \mathrm{l}$ and $1.5 \mathrm{~g} / \mathrm{l}$ of VE-Se in drinking water, respectively. The study was lasted 30 days period during summer season, Semen quality traits in terms of ejaculate volume $(\mathrm{ml})$, spermatozoa concentration $\left(\times 10^{9}\right)$, sperm motility $(\%)$, dead and live (\%), $\mathrm{PH}$ value and Abnormal sperms (\%) were determined. Sperm reserves in ducts, seminiferous tubules diameter (STD) and relative spermatogenic activity were also studied.

The obtained results indicated that addition of VE-Se improved ejaculate volume, sperm concentration and motility score, while reduced the percentage of abnormalities and dead sperms. Results showed that semen ejaculate volume was significantly increased $(P<0.05)$ as VE-Se levels increase. The same trend was also obtained with Spermatozoa concentration, progressive motility $(\%)$, and packed sperm volume were increased significantly with VE-Se treatment. The percentages of dead and abnormal spermatozoa were significantly decreased $(P<0.01)$ in VE-Se treated groups compared with the control drakes.

Concerning with the effect of VE-Se supplementation on the morphometric traits of testis, the obtained results showed that highly significant effects of antioxidant (VE-Se) supplementation on the morphometric of seminiferous tubules ( $p<$ 0.05 ) and the higher values of sperm reserves and spermatogenic activity percentage in both $T_{1}$ $\left(4.4 / \mathrm{ml} \times 10^{9}\right.$ and $\left.82.8 \%\right)$ and $\mathrm{T}_{2}\left(4.5 / \mathrm{ml} \times 10^{9}\right.$ and $83.0 \%)$ compared with control group $\left(3.2 / \mathrm{ml} \times 10^{9}\right.$ and $61.3 \%$ ). It could be concluded that VE-Se supplementation could lead to improved semen quality traits that increased reproductive efficiency within the ducks production subsequently greater economic benefits through this industry.

Keywords: Muscovy drakes, antioxidants, semen quality, seminiferous tubules diameter

\section{INTRODUCTION}

Vitamin $E$ is one of the best antioxidants for removal the oxidative stress in male reproductive system. Its use increases the reproductive functions and efficiency of male reproductive system. The deficiency of this vitamin leads to degeneration of germinal epithelium and Leydig cells in seminiferous tubules. The use of selenium and vitamin $E$ has the synergistic effects on the male reproductive system. Vitamin $E$ (a-tocopherol) is fat soluble organic compound and has the strong antioxidant properties and inhibits the lipid peroxidation created by the free hydroxyl and superoxide radicals. This vitamin protects the cell membrane of sperm cell from damages of reactive oxygen species (ROS). In an in vivo study, supplementation of vitamin $E$ was found to be effective in reduced number and motility of sperms caused by reactive oxygen species (Keskes-Ammar et al 2002). The supplementation of this vitamin through oral route has significant beneficial effects on motility of sperms through the reduction of malondialdehyde (MDA), which is known as the end product of lipid peroxidation (Suleiman et al 1996). 
On ganders, Jerysz and Lukaszewicz, (2013) reported that selenium is known as essential element for the testicular function and sperm motility. In Taiwan native chicken, lack of selenium element caused the testicular malfunctioning like atrophy of seminiferous tubules, abnormal spermatogenesis, immature sperms and reduction in volume of testes (Lin et al 2005). Vitamin $E$ possesses the enhanced effects on the sperm motility when given with selenium (Ahsan et al 2014). Numerous studies used selenium and vitamin E individually and/or in combine form either as supplementation in diet or in drinking water (Abdel-Fattah et al (2013) or as important components in semen extenders (Zubair et al 2015 and Kowalczyk et al 2017) they found an improvement of semen preservation capability due to their great effect on decreasing the reactive oxygen species production.

Spermatozoa and seminal plasma of duck semen were characterized by unexpectedly low content of vitamin E, being more than 4-fold lower than in chicken semen. In duck semen the major proportion of the vitamin $E(>70 \%)$ was located in the spermatozoa. Thus, the very high proportion of duck sperm lipids and the comparatively low levels of vitamin E could predispose semen to lipid peroxidation (Surai et al 2000). In a recent report by Ebeid (2012) the adverse effect of lipid peroxidation on male bird's semen quality and fertility was shown to be remedied with supplementation of exogenous vitamin E. Abdel-Fattah et al (2013) reported that, dietary antioxidants addition could effectively improve the Muscovy drakes ejaculate volume, concentration and motility score, while reduced the percentage of abnormalities and dead sperms, in particular with vit. E+Se followed by vit. A then, vit.C compared with the control Muscovy drakes.

Therefore, the use of antioxidants for spermatozoa preservation or dilution seems to be prerequisite for the regulating the successful fertility in the male reproductive system. Many studies proved that the use of vitamin $E$ has useful effects on the functions of fertility in chickens (Biswas et al 2009). The dietary supplementation of this vitamin protects the spermatozoa by maintaining the stability of polyunsaturated fatty acids in the cell membranes. The recommended dose of vitamin $E$ in poultry birds is $10 \mathrm{mg} / \mathrm{kg}$ of diet (Khan et al 2012).

Aiming to improve the semen quality of Muscovy, the purpose of the present study was to evaluate the effect of antioxidants (vitamin $E$ and selenium in combine form) supplementation in drinking water on different semen quality characteristics and to elucidate the beneficial effect of VE-Se on the seminiferous tubules diameter after 30 days of supplementation.

\section{MATERIALS AND METHODS}

\section{Birds, housing and environmental conditions}

Twelve Muscovy males at 36 weeks of age were used in this study that lasted 30days. All groups were kept individually in cages $(93 \times 70 \times 85$ $\mathrm{cm}$ ) on straw-lined floor and provided automatic drinking nipples throughout the experimental period, under similar environmental, managerial and hygienic conditions. Each drake was provided $350-400 \mathrm{~g} /$ day of diet contained $16 \%$ crude protein; $3.5 \%$ fat and $2600 \mathrm{kcal} \mathrm{ME} / \mathrm{kg}$ diet. Vitamin E and selenium contents of the diet were 20 and $0.14 \mathrm{mg} / \mathrm{kg}$, respectively. Prior to the onset of the experiment, drakes were trained for artificial collection of semen by massage technique. Twelve hours prior to semen collection birds were deprived of feed. The semen was collected individually in early morning hours. Collection procedure was always performed by the same persons at the same environment conditions.

\section{Experimental procedures}

Semen analysis started within 20 min of collection, the volume $(\mathrm{ml})$ of the ejaculate was determined using automatic pipette with an accuracy of $10 \mu \mathrm{l}$. (Lake and Stewart, 1978), the concentration of hydrogen ions was determined using $\mathrm{pH} 212$ Microprocessor pH Meter (Hanna Instruments), spermatozoa motility percentage was measured using a small droplet from each individual placed on a warm slide, covered with a cover slide and examined for spermatozoa motility microscopically at $400 \times$ magnification using a stage warmer set at 39º (Ebeid, 2009; Slowin'ska et al 2011). Spermatozoa motility was classified as described by Melrose and Laing (1970). Semen was given an arbitrary score from 0 to 5 based on the following assessment: 0 ( $0 \%$, no motility discernable); 1 (1 to $20 \%$ of spermatozoa exhibiting slight undulating movement; mostly weak and oscillatory); 2 (20 to $40 \%$ of spermatozoa showing undulating movement; no waves or eddies formed; there may be a number of inactive spermatozoa); 3 (40 to $60 \%$ of spermatozoa showing progressive motility; vigorous motion; slowly moving waves and eddies produced); 4 (60 to $80 \%$ of spermatozoa showing 
progressive motility; waves and eddies of great rapidity of formation and movement); and 5 (80 to $100 \%$ of spermatozoa in vigorous and progressive movement; extremely rapid formation of eddies and movement). Viability was estimated as the percentage of spermatozoa that were permeable to eosin; these were regarded as dead (Lake and Stewart, 1978). Sperm concentration in billion per milliliter $\left(\mathrm{spz} \times 10^{9} / \mathrm{ml}\right)$ was estimated using both haemocytometer using Potain's mixer and Thom Zeiss's chamber and sperm cell volume (PCV) method where the semen was drawn into microhaematocrit capillary tubes by gentle suction. One end of each tube was sealed on a propane gas flame. Two tubes were filled from each ejaculate. The tubes were centrifuged at 10,000 r.p.m. for 5 minutes in a standard micro-haematocrit centrifuge. After centrifugation, the percent packed cell volume was calculated using the graph supplied with the centrifuge, from which it is possible to read directly the percent packed cell volume without standardizing the amount of semen used. The technique was essentially the same as, Hickman (1958) described for bovine semen.

\section{Histological study}

At the end of experiment (on day 30 ), after semen collection, all birds in each treatment group $\left(\mathrm{C}, \mathrm{T}_{1}\right.$ and $\left.\mathrm{T}_{2}\right)$ were slaughtered and their testis was removed. Sperm reserves in ductus deferens of each drake were determined as reported by Onuora, (1984) The relative spermatogenic activity was also measured as the number of spermatids to spermatozoa /gm of testis tissue (Onoura, 1987). The tubular diameters of the seminiferous epithelium of the seminiferous tubules were measured with a standardized ocular micrometer.

\section{Statistical analysis}

The data concerning sperm parameters and histological study were performed using the statistical analysis system (SAS, 2006) on IBM 4300 series computer, while the significance of differences was verified by Duncan's multiple range test (1955).

\section{RESULTS AND DISCUSSION}

\author{
Effect of VE-Se supplementation on semen \\ characteristics
}

The key evaluation parameters of male reproductive system are volume, sperm motility, sperm concentration and fertilizing ability. Many studies proved that the use of vitamin E-Se in combine form has useful effects on the functions of fertility in chickens. In addition, the supplementation of vitamin $E$ caused the improvement through the number of epithelium, width of semineferous tubules as well as more number of Sertoli and Leydig cells. The deficiency of this vitamin leads to testicular degeneration in poultry, rats and hamster (Todorovic et al 2004) as well as the lower production of germ cells (Cooper et al 1987).

\section{Ejaculate volume and spermatozoa concentra- tion}

Ejaculation volume and sperm concentration determine how many females can be inseminated. The results of the different characteristics of semen quality are presented in Table (1). At the beginning of study (pre-supplementation), means \pm SE of ejaculate volume and sperm concentration recorded $\left(0.61,3.4 \times 10^{9}\right),\left(0.71,3.51 \times 10^{9}\right)$ and $(0.86 \mathrm{ml}$, $4.17 \times 10^{9}$ ) for control, $T_{1}$ and $T_{2}$ groups, respectively. At the end of the experimental period (postsupplementation), the corresponding values of ejaculate volume and sperm concentration were $\left(0.59,3.1 \times 10^{9}\right),\left(0.78,3.81 \times 10^{9}\right)$ and $(0.96 \mathrm{ml}$, $4.67 \times 10^{9}$ ) for $C, T_{1}$ and $T_{2}$ groups, respectively. The calculated rate of change for ejaculate volume was $-3.27,9.86$ and $11.63 \%$ for $\mathrm{C}, \mathrm{T}_{1}$ and $\mathrm{T}_{2}$ groups, respectively. The rates of change for spermatozoa concentration were -8.82, 8.55 and $11.99 \%$ for $C, T_{1}$ and $T_{2}$ groups, respectively. The results indicated that ejaculate volume and sperm concentration significantly increased $(P<0.01)$ with VE-Se supplementation. The enhancing was better on the level two $\left(T_{2}\right)$ of VE-Se supplementation compared with the level one $\left(T_{1}\right)$. The greater ejaculate volume collected and sperm concentration occurred with $T_{2}$ group at 30 days of supplementation of VE-Se. Previous studies reported 
that dietary vitamin $\mathrm{E}$ supplementation of a balanced poultry ration significantly supports reproductive functions, including semen volume, sperm concentration, sperm viability, sperm motility, and sperm capacity, in avian species (Khan et al 2012; Rakha et al 2015; Rengaraj and Hong, 2015).

\section{Sperm motility and prediction of sperm con-} centrations using PCV values

As the trend occurred in both ejaculate volume and spermatozoa concentration traits, a similar trend occurred in the progressive motility (PM) of the sperm and packed sperm volume (PCV \%), which was better in those drakes subjected to the level two of VE-Se $(1.5 \mathrm{~g} / \mathrm{l})$ than the level one $(1.0 \mathrm{~g} / \mathrm{l})$, the mean values of progressive motility percentage recorded $65.8 \pm 14.5,75.3 \pm 11.0$ and $72.3 \pm 9.94 \%$ for $C, T_{1}$ and $T_{2}$ groups, respectively at pre-supplementation. The corresponding values at post-supplementation (on day 30 ) were $55.3 \pm$ 16.2, $79.2 \pm 10.7$ and $81.3 \pm 9.54 \%$ for $C, T_{1}$ and $\mathrm{T}_{2}$ groups, respectively. Cyriac et al (2013) reported that the motility in Muscovy semen was slightly higher and this might be due to the watery consistency of Muscovy semen and also because of the lower spermatozoa concentration in Muscovy drake semen. On the other hand Gvaryahu (1984) and Etuk et al (2006) reported a motility score of 3.59 and a motility of $68.58 \%$ in Muscovy drakes which was in agreement with the present findings. Also,

Asl et al (2018) studied the effect of supplementation of two levels of vitamin $E$ (zero and $200 \mathrm{mg} / \mathrm{kg}$ diet) for 60 days period on semen characteristics of Ross broiler breeder roosters and found that the 0.16 dietary ratio supplementation with 200mgVitE improved total sperm motility $(P<0.05)$ than the 0.09 and 0.23 ratio and reduced the lipid peroxidation of rooster sperm $(\mathrm{P}<0.05)$ in addition in the artificial insemination the higher significant percentage of fertility rate $(P=0.02)$ compared with the other groups.

The mean values of packed sperm volume recorded $9.1 \pm 1.4,10.1 \pm 1.10$ and $10.2 \pm 1.03 \%$ for $C$, $\mathrm{T}_{1}$ and $\mathrm{T}_{2}$ groups, respectively at presupplementation. The corresponding values at post-supplementation (on day 30 ) were $8.3 \pm 1.7$, $10.5 \pm 1.10$ and $12.2 \pm 1.07 \%$ for $\mathrm{C}, \mathrm{T}_{1}$ and $\mathrm{T}_{2}$ groups, respectively. Based on our observation, PCV values could be used as prediction for a quick estimation of sperm concentration of Muscovy drakes.

Table 1. Effect of Vitamin E- Se supplementation on some semen characteristics of Muscovy drakes during summer season

\begin{tabular}{|c|c|c|c|c|c|c|c|}
\hline \multirow{2}{*}{ Groups } & \multicolumn{7}{|c|}{ Semen characteristics } \\
\hline & Vol. & PM\% & CON. & PCV\% & pH & DS\% & Abn. \% \\
\hline \multicolumn{8}{|c|}{ Pre-supplementation (Zero time) } \\
\hline Control & $0.61 \pm 0.05$ & $65.8 \pm 14.5^{\mathrm{b}}$ & $3.4 \pm 0.43^{b}$ & $9.1 \pm 1.4^{b}$ & $7.2 \pm 0.09^{N S}$ & $24.3 \pm 3.42^{b}$ & $31.5 \pm 4.72^{b}$ \\
\hline $\mathrm{T}_{1}$ & $0.71 \pm 0.10^{b}$ & $75.3 \pm 11.0^{b}$ & $3.51 \pm 0.32^{b}$ & $10.1 \pm 1.10^{b}$ & $6.99 \pm 1.50^{\mathrm{NS}}$ & $18.7 \pm 2.50^{b}$ & $19.6 \pm 3.30^{b}$ \\
\hline $\mathrm{T}_{2}$ & $0.86 \pm 0.22^{b}$ & $72.3 \pm 9.94^{b}$ & $4.17 \pm 0.63^{b}$ & $10.2 \pm 1.03^{b}$ & $6.97 \pm 1.02^{\mathrm{NS}}$ & $14.4 \pm 1.35^{\mathrm{c}}$ & $15.3 \pm 2.01^{\mathrm{c}}$ \\
\hline \multicolumn{8}{|c|}{ Post 30 days of supplementation } \\
\hline & Vol. & PM\% & CON. & $\mathbf{P C V}^{\%}$ & pH & DS\% & Abn. \% \\
\hline Control & $0.59 \pm 0.06$ & $55.3 \pm 16.2^{\mathrm{a}}$ & $3.1 \pm 0.51^{\mathrm{a}}$ & $8.3 \pm 1.7^{\mathrm{a}}$ & $7.1 \pm 0.09^{b}$ & $34.3 \pm 3.96^{\mathrm{a}}$ & $41.5 \pm 5.32^{\mathrm{a}}$ \\
\hline $\mathrm{T}_{1}$ & $0.78 \pm 0.10^{b}$ & $79.2 \pm 10.7^{a}$ & $3.81 \pm 0.32^{\mathrm{a}}$ & $10.5 \pm 1.10^{\mathrm{b}}$ & $6.81 \pm 1.30^{\mathrm{a}}$ & $16.6 \pm 2.30^{a}$ & $18.4 \pm 3.50^{\mathrm{a}}$ \\
\hline $\mathrm{T}_{2}$ & $0.96 \pm 0.32^{\mathrm{a}}$ & $81.3 \pm 9.54^{\mathrm{a}}$ & $4.67 \pm 0.51^{a}$ & $12.2 \pm 1.07^{\mathrm{a}}$ & $6.79 \pm 1.02^{\mathrm{a}}$ & $12.4 \pm 1.75^{\mathrm{c}}$ & $10.6 \pm 2.05^{c}$ \\
\hline
\end{tabular}

a,b,c..means in the same row with different superscripts are significantly different $(P \leq 0.05)$; NS= non-significant Vol= sperm volume, $\mathrm{PM}=$ progressive motility, $\mathrm{CON}=$ sperm concentration, $\mathrm{PCV}=$ paked cell (sperm).volume, DS=dead sperm, Abn=Abnormal spermatozoa, 

of Muscovy drakes

\section{Semen pH}

As shown in Table (1) the values of semen $\mathrm{pH}$ for all the three experimental groups $\left(C, T_{1}\right.$ and $\left.T_{2}\right)$ showed no significant differences in pre and postsupplementation of VE-Se and was similar with the findings of Gvaryahu et al., (1984) and Cyriac et al (2013) who observed semen $\mathrm{pH}$ in Muscovy drakes which was similar to that obtained in the present study. On the contrary, Etuk et al. (2006) reported higher $\mathrm{pH}$ in Muscovy drakes under different management systems, viz. semi intensive, intensive system with wallow and intensive system without wallow.

Analysis of variance showed that the $\mathrm{pH}$ values of semen on day 30 (post-supplementation) were significantly $(\mathrm{P}<0.05)$ decreased $(-1.41 \%,-2.57 \%$ and $-2.58 \%$ for $C, T_{1}$ and $T_{2}$ groups, respectively) It may be due to VE-Se supplementation. Similar observation was also reported by Gvaryahu et al (1984). The increase in spermatozoa concentration was associated with a decline in the $\mathrm{pH}$ value of the semen. This may be attributed to the higher metabolic activity of spermatozoa which, in turn resulting in increased quantity of metabolites mainly lactic acid, that causes a decrease in the $\mathrm{pH}$ value. However, Lake (1971) postulated that acidic environment is not favorable to spermatozoa, yet the seminal fluids of drakes of the present study were not acidic as evidenced by the $\mathrm{pH}$ values obtained.

\section{Dead and abnormal spermatozoa percentages}

The percentages of dead and abnormality of sperms are presented in Table (1). The results indicated that the higher percentage of abnormal sperm in the control group when compared to the treated groups $\left(T_{1}\right.$ and $\left.T_{2}\right)$ may be attributed to oxidative stress (the high quantity of polyunsaturated fatty acids in the sperm composition).
Cyriac et al (2013) mentioned that if the head abnormalities are more than 3 to $5 \%$, the semen sample is not suitable for artificial insemination and the total abnormalities permitted are 15 to $20 \%$. From our results, it was evident that the percent of abnormal spermatozoa was within normal levels and hence the samples are suitable for artificial insemination. The abnormalities affect the movement and livability of the sperms in the reproductive tract of female and thereby result in fertilization failure. The results observed in the present study were in close agreement with that reported by Kamar (1962) in Pekin drakes, Gvaryahu et al (1984) in Muscovy drakes and Ghonim et al $(2009,2010)$ in Domyati drakes.

Finally, Ebeid, (2012) reported that dietary vitamin $E$ in combination with organic Se has a synergistic effect in minimizing lipid peroxidation and improving the antioxidative status in seminal plasma of the domestic fowl, which probably translated into enhanced spermatozoa count, motility and reduced percentage of dead spermatozoa under heat stress conditions.

\section{Effect of VE-Se supplementation on some structural composition of testes}

Recent studies were performed by Okpi et al (2010); Okpi and Udoumoh (2016) on Nigerian local chickens and Nigerian drakes, respectively. The results reported that the volume of the testes occupied by seminiferous tubules and the increase in the parameters of the seminiferous tubule tissues and daily sperm production probably resulted from enhanced testosterone secretion and Sertoli cell efficiency due to increases observed in the relative volume densities of Leydig cells and lumen diameter, respectively.

It is worth mentioning that the use of selenium and vitamin $E$ has the synergistic effects on the male reproductive system. The deficiency of this vitamin leads to degeneration of germinal epithelium and Leydig cells in seminiferous tubules (Zubair, 2017). 
Table 2. Effect of Vitamin E- Se supplementation on sperm reserves, seminiferous tubules diameter (STD); spermatozoa concentration (Conc.) and relative spermatogenic activity of Muscovy drakes during summer season

\begin{tabular}{|c|c|c|c|c|}
\hline Experimental groups & Sperm Res. $/ \mathbf{m l \times 1 0 ^ { 9 }}$ & STD $(\boldsymbol{\mu m})$ & Conc. $\times 10^{\mathbf{9}} / \mathbf{g m}$ & Spermatogenic activity $(\%)$ \\
\hline Control & $3.2 \pm 0.83^{\mathrm{b}}$ & $312.8 \pm 26.2^{\mathrm{b}}$ & $5.1 \pm 0.89^{\mathrm{b}}$ & $61.3 \pm 5.5^{\mathrm{b}}$ \\
$\mathbf{T}_{1}$ & $4.4 \pm 0.95^{\mathrm{a}}$ & $494.6 \pm 34.2^{\mathrm{a}}$ & $7.50 \pm 1.24^{\mathrm{a}}$ & $82.8 \pm 7.4^{\mathrm{a}}$ \\
$\mathbf{T}_{2}$ & $4.5 \pm 0.99^{\mathrm{a}}$ & $494.9 \pm 34.3^{\mathrm{a}}$ & $7.49 \pm 1.26^{\mathrm{a}}$ & $83.0 \pm 7.3^{\mathrm{a}}$ \\
\hline
\end{tabular}

STD = Mean of 24 tubules diameter (micron)

a,b,c. means in the same row with different superscripts are significantly different( $P \leq 0.05)$

Conc. $=$ sperm concentration

As shown in Table (2) the sperm reserves in the ducts deferens of Muscovy were significantly higher. Similar trends were also observed in the seminiferous tubules diameter, spermatozoa concentration per gram of testis and the relative spermatognic activity.

The morphometric measurement of seminiferous tubules diameter observed in the present study is presented in Table 2. We observed highly significant effects of antioxidant (VE-Se) supplementation on the morphometric of seminiferous tubules $(p<0.05)$. The higher values of sperm reserves and spermatogenic activity percentage in both $\mathrm{T}_{1}\left(4.4 / \mathrm{ml} \times 10^{9}\right.$ and $\left.82.8 \%\right)$ and $\mathrm{T}_{2}\left(4.5 / \mathrm{ml} \times 10^{9}\right.$ and $83.0 \%$ ) compared with control group $\left(3.2 / \mathrm{ml} \times 10^{9}\right.$ and $\left.61.3 \%\right)$ due to the vital role of VESe in preventing the ROS which can effect on various cell functions through inhibition of many cytosolic enzymes (Szabó et al 2007).

The results in Table (2) indicated that after 30days from the onset of the experiment, there was significant $(P<0.05)$ increased diameter of seminiferous tubules of testes in both $T_{1}$ (494.6 $\mu \mathrm{m})$ and $\mathrm{T}_{2}(494.9 \mu \mathrm{m})$ compared with control group $(312.8 \mu \mathrm{m})$, the rate of change recorded $58.1 \%$ and $58.2 \%$ for $\mathrm{T}_{1}$ and $\mathrm{T}_{2}$ groups, respectively. The increase in the parameters of the seminiferous tubule tissues and daily sperm production probably resulted from enhanced testosterone secretion and Sertoli cell efficiency due to increases observed in the relative volume densities of Leydig cells and lumen diameter, respectively.

Testosterone hormone plays a vital role in the maintenance of spermatogenesis by enhancing cell division and minimizing apoptosis. Similarly, the size of the seminiferous tubule lumen is determined by the volume of seminiferous tubule fluid and the effectiveness of blood-testis barrier (Tindall et al 1975).

The testes fulfill two important functions within the male body: spermatogenesis takes place in the seminiferous tubules of the testes (Whittow 2000) and the production of androgens (e.g. secretion of testosterone) occurs in the Leydig cells of the interstitial tissue (Lofts and Murton 1973). Both gonadal functions strongly affect male reproductive success through male-male competition and mate choice. The beneficial effect of vitamin $E$ is mostly due to its antioxidant potentials.

Finally, the current study could conclude that VE-Se supplementation at two levels in drinking water of Muscovy drakes for 30 days showed that the architecture of most of the seminiferous tubules was highly preserved with enhanced spermatogenesis and the lumen of the tubule was full of sperms, and consequently their quality.

\section{CONCLUSION}

The results showed that supplementing Vitamin E-Se combined in drinking water at the concentration of $1.0 \mathrm{~g} / \mathrm{l}$ and $1.5 \mathrm{~g} / \mathrm{l}$ respectively, for one month during summer season have a positive effect in increasing significantly semen quality and quantity $(P<0.05)$, the optimal level of Vitamin E-Se supplementation in drinking water had higher useful in improving semen volume, enhance sperm number and decreased dead sperms percentage.

\section{REFERENCES}

Abdel-Fattah S.A., Badri F.B.A. and El-Wardany I. 2013. Effect of supplemental antioxidants vitamins on semen quality and some physicochemical traits in Muscovy drakes. Egyptian J. Nutrition and Feeds. 16(3), 1-12. 

of Muscovy drakes

AsI R.S., Shariatmadari F., Sharafi M., Torshizi M.A.K. and Shahverdi M. 2018. Improvements in semen quality, sperm fattyacids and reproductive performance in aged Ross breeder roosters fed a diet supplemented with a moderate ratio of $n-3: n-6$ fatty acids. Poultry Sci. 97, 4113-4121.

Biswas A, Mohan J. and Sastry K.V. 2009. Effect of higher dietary vitamin $\mathrm{E}$ concentrations on physical and biochemical characteristics of semen in Kadaknath cockerels. Br. Poult. Sci. 50, 733-738.

Cooper D.R., King O.R. and Carpenter M.P. 1987. Effect of Vitamin $E$ deficiency on serum concentrations of follicle stimulating hormone and testosterone during testicular maturation and degeneration. Endocrinology 120, 83-90.

Cyriac S.L., Joseph P.A., Narayanankutty K. and Karthiayini K. 2013. Semen quality characteristics of White Pekin, Kuttanad (Anas platyrhynchos domesticus) and Muscovy (Cairina moschata momelanotus) drakes. Indian J. of Animal Sci. 83(6), 595-599.

Duncan D.B. 1955. Multiple range and multiple $F$ tests. Biometrics, 11, 1-42.

Ebeid T.A. 2009. Organic selenium enhances the antioxidative status and quality of cockerel semen under high ambient temperature. British Poultry Sci., 50, 641-647.

Ebeid, T.A. 2012. Vitamin E and organic selenium enhances the antioxidative status and quality of chicken semen under high ambient temperature. Bri. Poult. Sci., 53, 708-714.

Etuk I.F., Ojewola G.S. and Nwachukwu E.N. 2006. Effect of management systems on semen quality of Muscovy drakes. International J. of Poultry Sci. 5, 482-484.

Ghonim A.I.A, Awad A.L., El.sawy A.M., Fatouh M.H. and Ibraheim Z.A. 2009. Effect of frequency of semen collection, dilution rate and insemination dose on semen characteristics and fertility of Domyati ducks. Egyptian J. of Poultry Science 29, 1023-1045.

Ghonim A.I.A, Awad A.L., Elkloub K. and El-Moustafa M. 2010. Effect of feeding different levels of energy and crude protein on semen quality and fertility of Domyati ducks. Egyptian J. of Poultry Sci. 30, 583-600.

Gvaryahu G., Robinzon G., Meltzer B., Perck M. and Snapir N. 1984. An improved method for obtaining semen from Muscovy drakes and some of its quantitative and qualitative characteristics. Poultry Sci. 63, 548-553.
Hickman C.G. 1958. Spermatocrit values in facilitating the estimation of spermatozoa concentrations. J. Dairy Sci. 41, 318-319.

Jerysz A. and Lukaszewicz E. 2013. Effect of dietary selenium and vitamin $E$ on ganders' response to semen collection and ejaculate characteristics. Biol. Trace Elem. Res. 153, 196204.

Kamar A.R.G. 1962. Semen characteristics of various breeds of drakes in the sub tropics. J. of Reproduction and Fertility 3, 405-409.

Keskes-Ammar L., Feki-Chakroun N., Rebai T., Sahnoun Z., Ghozzi H. and Hammami S. 2003. Sperm oxidative stress and the effect of an oral vitamin $\mathrm{E}$ and selenium supplement on semen quality in infertile men. Arch Androl. 49(2), 83-94.

Khan R.U., Rahman Z.U., Javed I. and Muhammad F. 2012. Effect of vitamins, probiotics and protein on semen traits in post-molt male broiler breeders. Anim. Reprod. Sci. 135, 85-90.

Kowalczyk A.M., Klećkowska-Nawrot J. and Łukaszewicz E.T. 2017. Effect of selenium and vitamin $E$ addition to the extender on liquid stored capercaillie (Tetrao urogallus) semen quality. Reproduction in Domesticated Animals 52, 603-609.

Lake P.E. 1971. The male is reproduction. chapter 60. In: Bell, D.J. and Freeman, B.M. (eds.). Physiology and biochemistry of the domestic fowl. Academic Press, New York, USA, pp. 160-184.

Lake P.E. and Stewart J.M. 1978. Artificial insemination in poultry, Ministry of Agric., Fisheries and Food Bulletin. London, Her Majesty's Stationary Office at HMSO Press, No. 213, pp. 135.

Lin Y.F., Chang S.J., Yang J.R., Lee Y.P. and Hsu A.L. 2005. Effects of supplemental vitamin $\mathrm{E}$ during the mature period on the reproduction performance of Taiwan native chicken cockerels. Br Poult. Sci. 46, 366-373.

Lofts B. and Murton R.K. 1973. Reproduction in birds. In: Avian Biology, Farner D.S., King J.R. and Parkes K.C., (eds.), London Academic Press, No.7, pp. 107-117.

Mekrose D.R. and Laing J.A. 1970. Fertility and Infertility in the Domestic Animals, $2^{\text {nd }}$ Ed. London, Bailliere Tindall, pp. 130-141.

Okpe G.C., Nwatu U. and Anya K. 2010. Morphometric study of the testes of the Nigerian local breed of chicken. Anim. Res. Int. 7, 1163-1168. 
Okpe G.C. and Udoumoh A.F. 2016. Effect of season on structural composition of drake testes and daily spermatozoa production as determined by quantitative testicular histology. Med. Weter, 72(10), 627-631.

Onuora G.I. 1984. percent sperm reserves in different parts of the genital tract in two strains of guinea-fowl. In $10^{\text {th }}$ inter. Cong. Animal Production and Ai., Illinois, USA. pp. 261-265.

Onuora G.I. 1987. Spermatogenic activities of the left and right testes of hemicasterated and intact cockerels. Animal Repord. SCI., 14, 157164.

Rakha B.A., Ansari M.S., Hussain I., Malik M.F., Akhter S. and Blesbois E. 2015. Semen characteristics of the Indian Red Jungle Fowl (Gallus gallus murghi). European J. of Wildlife Research 61, 379-386.

Rengaraj D. and Hong Y.H. 2015. Effect of dietary vitamin $E$ on fertility functions in poultry species. International J. of Molecular Sci. 16, 9910-9921.

SAS 2006 SAS/STAT User's Guide: Statistics Ver. 9.1.3, 5th ed. SAS Institute Inc. Cary.

Slowin'ska M., Jankowski J., Dietrich G.J., Karol H., Liszewska E., Glogowski J., Kozlowski K., Sartowska K. and Ciereszko A. 2011. Effect of organic and inorganic forms of selenium in diets on turkey semen quality. Poultry Sci., 90, 181-190.

Suleiman S.A., Ali M.E., Zaki Z.M., El-Malik E.M. and Nasr M.A. 1996. Lipid peroxidation and human sperm motility. Protective Role of Vitamin E.J. Androl. 17, 530-537.
Surai P.F., Brillard J.P., Speake B.K., Blesbois E., Seigneurin F. and Sparks N.H.C. 2000. Phospholipid fatty acid composition, vitamin E content and susceptibility to lipid peroxidation of duck spermatozoa. Theriogenol. 53, 10251039.

Szabó C., Ischiropoulos H. and Radi R. Peroxynitrite 2007. Biochemistry, pathophysiology and development of therapeutics. Nat Rev Drug Discov 2007; 6, 662-680.

Tindall D.J., Vitale R. and Means A.R. 1975. Androgen binding protein as a biochemical marker of formation of the blood-testis barrier. Endocrinol. 97, 636-648.

Todorovic M., Jokic Z. and Davidovic V. 2004. The influence of selenium and Vitamin $E$ in poultry nutrition. Biotech Anim Husb. 18, 231238.

Whittow G.C.E. 2000. Avian physiology. Reproduction in the male In: New Brunswick, USA, pp. 432-451.

Zubair M., Ali M., Ahmad M., Sajid S.M., Ahmad I. and Gul S.T. 2015. Effect of Selenium and Vitamin $E$ on cryopreservation of semen and reproductive performance of animals. J. of Entomology and Zoology Studies, 3, 82-86.

Zubair M. 2017. Effects of dietary vitamin $E$ on male reproductive system. Asian Pacific J. of Reproduction, 6(4), 145-150. 
تأثير إضـافة مُضادات الأكسدة (فيتامين هـ والسيلينيوم) في ماء الشُرب على بعض صفات السائل المنوي لذكور البط المسكوفي ه مابني

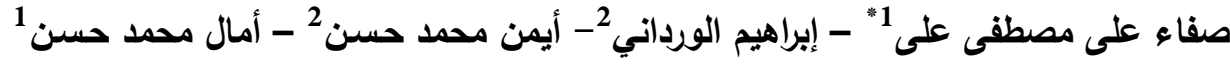

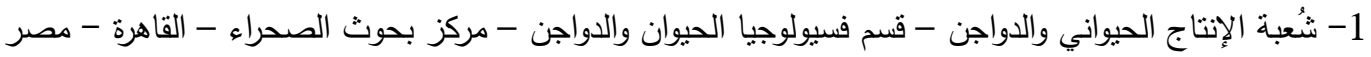 \\ 2- قسم إنتاج الدواجن - كلية الزراعة - جامعة عين شمس - ص.ب ولب 68- حدائق شبرا 11241 - القاهرة - مصر
}

*Corresponding author: safaaali30@yahoo.com

Received 30 April, 2019

Accepted 30 May, 2019

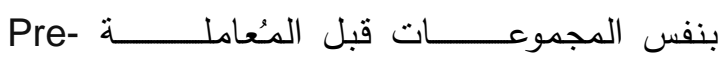
supplementation

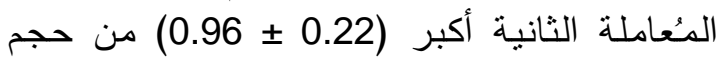

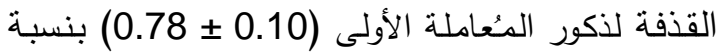

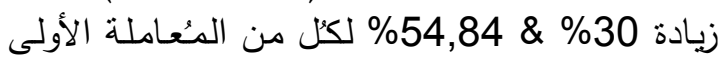

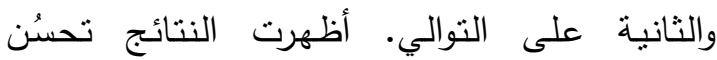
ملحوظ في النسبة المئوية لحركة الإسبرمات بعات بعد

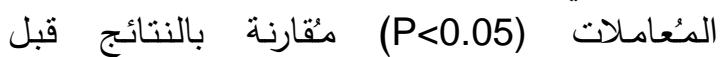

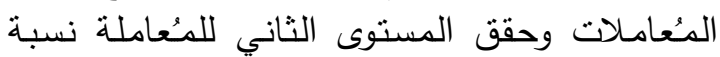

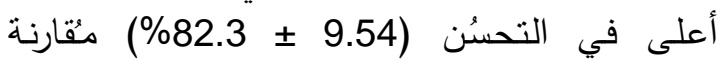

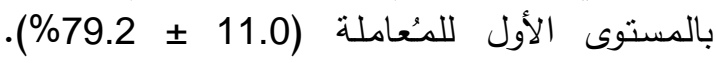

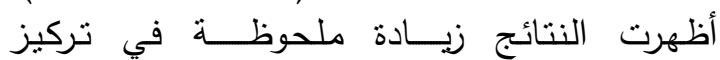
الإسبرمات P>0.05 P (الحيوانات المنوية) وكذلك حجم الإسبرمات المضغنوطة للمجموعات المئعاملة P<0.01 معنويـاً Post-supplementation Pre- مُقارنة بنفس المجموعات قبل المُعاملة supplementation

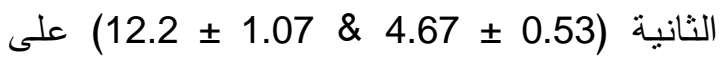

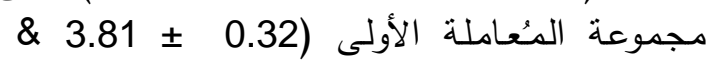
ود1.10 10.5) في قيم كل من تركيز الإسبرمات

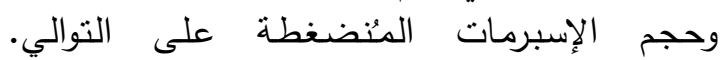

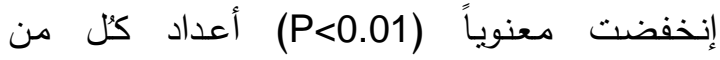
الإسبرمات الثاذة وكذللك الإسبرمات الميتة في في اعنيات

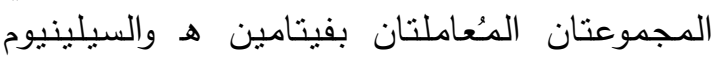

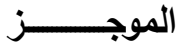

أجريت الدراسة على عدد 12 ذكر بط مسكوفي عند عُمر 36 أسبوع عوزئ عردين عشوائيا في ثناث

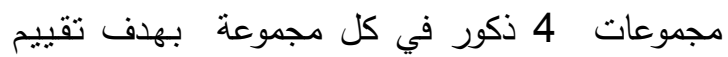

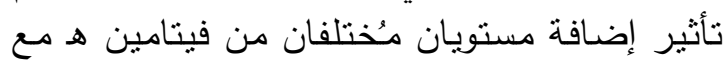

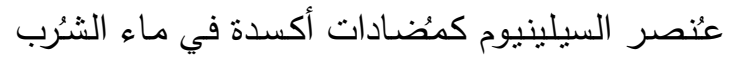
على بعض صفات السائل المنوب وبعض القيادئ القياسات المورفومترية للخصية ثم جمع عينات السائل المنات المنوي من جميع الطيور قبل إضـافة المُعامـلات

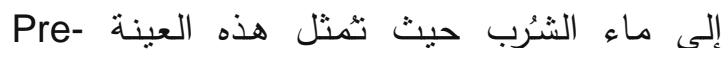

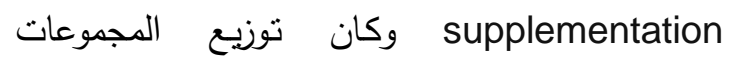
التجريبية كالتالي: المجموعة الأولى (مجموعة المبعة

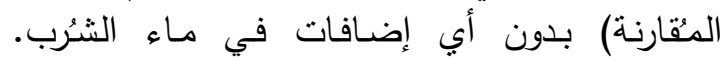

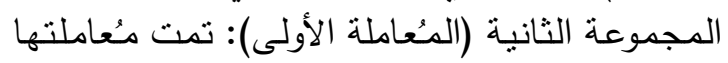

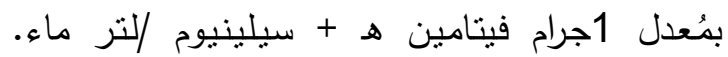
المجموعة الثالثة (المُعاملة الثانية) تمت فئن مُعاملتها بمُعدل 1,5جرام فيتامين هـ +سيلينيوم /لتر ماء.

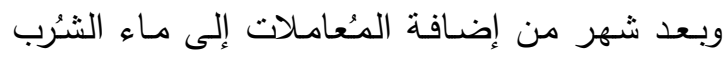

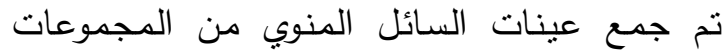
التجريبية الثناثة حيث نمثنل هذه العينة -Post. supplementation

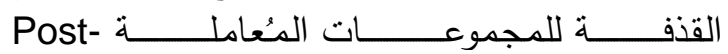
معنوياً (P< supplementation 
اليوم الـ 30 مُقارنة بعينة الـ Zero time بينما

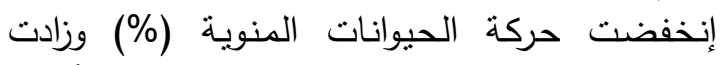
نسبة الإسبرمات الثاذة (\%) وكذلك نسبة أعداد

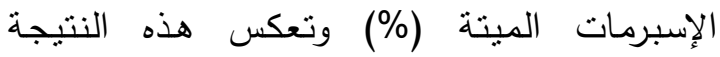

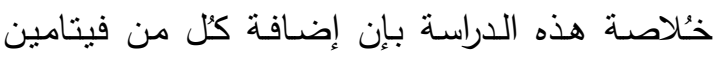

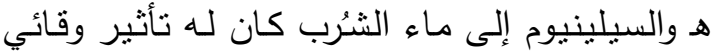

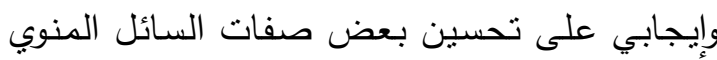
والذي من المُمكن أن ينعكس ذلك على مُعدل

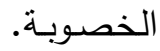

الكلمات الدالة: ذكور بط المسكوفي، مضادات الأكسدة، جودة السائل المنوي، قطر الأنابيب المنوية
مُقارنة بالمجموعة الضابطة وحقق المستوى الثاني

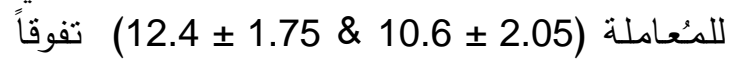

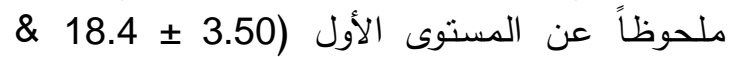
2.3

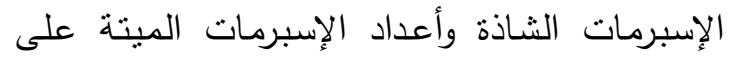

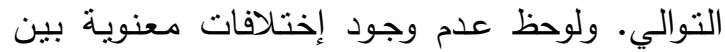
المجموعات المُعاملة والمجموعة الضمابطة فئة فيما

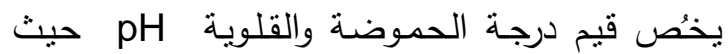

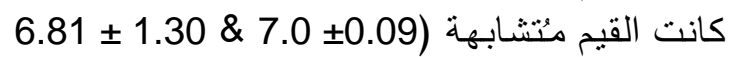

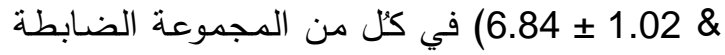
ومجموعتي المستوى الأول والثاني على فلى التوالي. كذلك لم يتأثر حجم القذفة للمجموعة الضابطة عند الصن 